\title{
SPECTRAL EVALUATION AND ANTIMICROBIAL ACTIVITY OF SYNTHESIZED 4H-1,4-BENZOTHIAZINES
}

\author{
ARUN GOYAL* \\ Department of Chemistry, Govt. P.G. College Rajgarh (Alwar), Rajasthan, Alwar, India. Email: arunchemphd@gmail.com
}

Received: 23 February 2021, Revised and Accepted: 09 April 2021

\begin{abstract}
Objective: 4H-1,4-Benzothiazines constitute an important class of heterocycles containing 1,4-thiazine ring fused to benzene ring. They are extensively used as tranquilizer, antispasmodic, central nervous system depressant, antiulcer, antibacterial, antifungal, antioxidant, anticancer agents, fungicides, etc. Therefore, these observations prompted us to synthesize substituted $4 H$-1,4-benzothiazines and investigate their antimicrobial activity against selected bacterial and fungal strains.
\end{abstract}

Methods: In the present research work, 2-Amino-3,5,6-trichlorobenzenethiol condensed with $\beta$-diketones/ $\beta$-ketoesters in the presence of dimethyl sulfoxide followed by oxidative cyclisation leading to the formation of $4 H$-1,4-benzothiazines. The spectral investigation confirmed the synthesis of these bioactive compounds. All synthesized compounds were screened for their antimicrobial activity (antibacterial and antifungal) using agar well diffusion method.

Results: The minimum inhibitory concentration values of synthesized compounds gave excellent results against bacterial as well as fungal strains (Escherichia coli [Gram negative] MTCC 2939, 58-158 $\mu \mathrm{g} / \mathrm{mL}$, Bacillus subtilis [Gram positive] MTCC 441, 41-124 $\mu \mathrm{g} / \mathrm{mL}$, Streptomyces griseus [Gram negative] MTCC 1998, 85-128 $\mu \mathrm{g} / \mathrm{mL}$, Fusarium oxysporum MTCC 1755, 142-151 $\mu \mathrm{g} / \mathrm{mL}$, Aspergillus niger MTCC 281, 59-78 $\mu \mathrm{g} / \mathrm{mL}$, and Rhizopus stolonifer MTCC 2591, 85-118 $\mu \mathrm{g} / \mathrm{mL})$.

Conclusion: Synthesized substituted benzothiazines have potential to be used as a new class of antibacterial and antifungal drugs. Further biomedical research is required to make $4 H$-1,4-benzothiazines related compounds as potential antibacterial and antifungal drugs.

Keywords: Benzothiazine, $\beta$-diketones $/ \beta$-diketoesters, Antimicrobial properties.

(C) 2021 The Authors. Published by Innovare Academic Sciences Pvt Ltd. This is an open access article under the CC BY license (http://creativecommons.org/ licenses/by/4.0/) DOI: http://dx.doi.org/10.22159/ajpcr.2021v14i6.41193. Journal homepage: https://innovareacademics.in/journals/index.php/ajpcr

\section{INTRODUCTION}

Synthesized 4H-1,4-benzothiazines [1-8] have widespread therapeutic uses such as vasodilator, neuroleptic, tranquilizer [9], sedative, antispasmodic, central nervous system depressant [10], dyestuff, copolymer, and flavoring agent. Distinguishable difference observed in their pharmacological activities [11-14] due to slight change in the substitution pattern in benzothiazine nucleus. The simplicity and diversity of synthetic methods as well as their pharmacological, biological, and industrial significance also make them important for research. Benzothiazine also possesses a distinguished property according to which a slight change in the substitution pattern causes major differences in their biological activities [15-18]. This opens a gate to synthesize a number of antimicrobial agents. Thus knowing the immense importance of benzothiazine template, we have synthesized substituted $4 H-1,4$ benzothiazines. To exhibit the potential of synthesized compounds as better antimicrobial agents minimum inhibitory concentration (MIC) [19-20] against selected strains of fungi, Gram-positive and Gramnegative bacteria belonging to Microbial Type Culture Collection (MTCC) were reported using broth microdilution method.

\section{RESULTS AND DISCUSSION}

\section{Chemistry}

In the presence of dimethyl sulfoxide (DMSO), 2-Amino-3,5,6trichlorobenzenethiol (I) condensed with $\beta$-diketones/ $\beta$-ketoesters (IIa) followed by oxidative cyclization. Bis-(2-aminophenyl) disulfides (Ia) formed from substituted 2-aminobenzenethiols (I) due to readily oxidation, which undergoes cyclization by scission of S-S bond due to high reactive $\alpha$-position of enamino ketone system (III) toward intramolecular nucleophilic attack leading to the formation of 4H-1,4-benzothiazines (Scheme 1).

$\beta$-Diketones and $\beta$-ketoesters usually exist in two isomeric forms (ketoenol tautomerism) IIa and IIb (Fig. 1). Therefore, there is a possibility of the formation of two types of 1,4-benzothiazines (IV) and (VI), but only one type of 1,4-benzothiazines (IV) is separated (Scheme 1). Elemental analysis and spectral data support the proposed structures of reported compounds.

Synthesized substituted 4H-1,4-benzothiazines are summarized below: Iva Isopropyl-5,7,8-trichloro-3-methyl-4H-1,4-benzothiazine-2carboxylate.

IVb Ethyl-5,7,8-trichloro-3-propyl-4H-1,4-benzothiazine-2-carboxylate.

Spectral Evaluation and Antimicrobial Activity

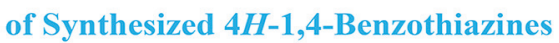
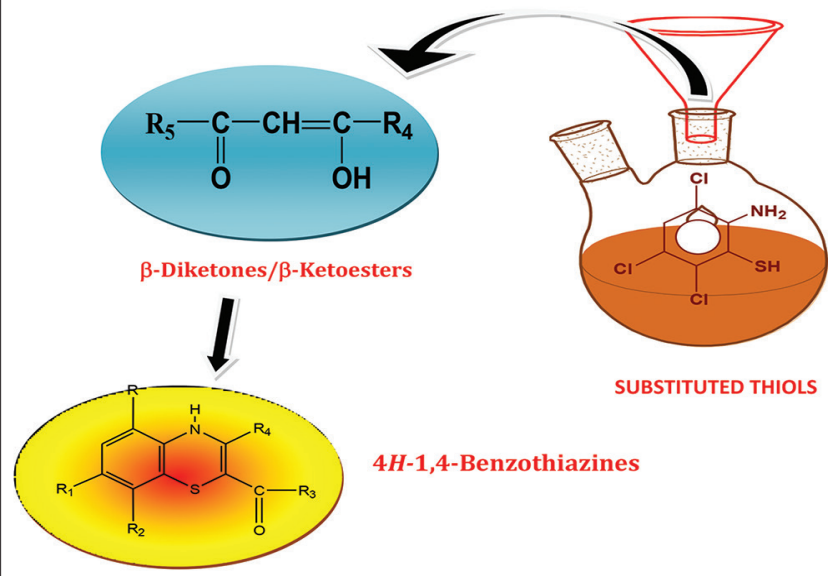

4H-1,4-Benzothiazines 
IR SPECTRA

All the 4H-1,4-benzothiazines exhibit a single sharp peak in the region $3465-3350 \mathrm{~cm}^{-1}$ due to $\mathrm{N}-\mathrm{H}$ stretching vibrations. These also exhibit a sharp band due to $>\mathrm{C}=\mathrm{O}$ stretching vibrations of carbonyl group at $1720-1710 \mathrm{~cm}^{-1}$. In compound IVa-b, C-O-C asymmetric and symmetric vibrations occur in region $1270-1265 \mathrm{~cm}^{-1}$ and $1080-1060 \mathrm{~cm}^{-1}$.

Compounds IVa-b exhibit sharp bands in the region 2960-2955 $\mathrm{cm}^{-1}$ and $2830-2825 \mathrm{~cm}^{-1}$ due to $\mathrm{C}-\mathrm{H}$ asymmetric and symmetric stretching vibrations of $\mathrm{CH}_{3}$ group. Compounds IVa-b also show two sharp bands in the region $1460-1455 \mathrm{~cm}^{-1}$ and $1340-1335 \mathrm{~cm}^{-1}$ due to C-H deformation<smiles>[R]C(=O)C=C([R])O</smiles>

IIa<smiles>[R4]C(O)=CC(=O)B1C=C1</smiles>

IIb
Fig. 1: Keto-Enol Tautomerism in $\beta$-Diketones and $\beta$-ketoesters vibrations of $\mathrm{CH}_{3}$ group. In compounds IVa-b, $\mathrm{C}-\mathrm{Cl}$ stretching vibrations occur in the region $810-800 \mathrm{~cm}^{-1}$

\section{${ }^{1} \mathrm{H}$-NMR spectra}

All the synthesized benzothiazines exhibit a single sharp peak in region $\delta$ 9.47-9.28 ppm due to $>\mathrm{N}-\mathrm{H}$ proton. The singlet is observed at $\delta 8.12-$ $8.10 \mathrm{ppm}$ due to single aromatic proton in compounds IVa-b. Compound IVa shows singlet at $\delta 1.85 \mathrm{ppm}$ due to $-\mathrm{CH}_{3}$ protons at $\mathrm{C}_{3}$ Multiplet observed at $\delta 4.82 \mathrm{ppm}$ due to $\mathrm{CH}$ proton of $-\mathrm{OCH}\left(\mathrm{CH}_{3}\right)_{2}$ group at $\mathrm{C}_{2}$ and doublet observed at $\delta 1.90 \mathrm{ppm}$ due to $-\mathrm{CH}_{3}$ proton of $-\mathrm{OCH}\left(\mathrm{CH}_{3}\right)_{2}$ group at $\mathrm{C}_{2}$. In compounds IVb triplet, sextet observed in the region $\delta$ 2.10-1.42 ppm due to $>\mathrm{CH}_{2}$ protons of $\mathrm{C}_{3} \mathrm{H}_{7}$ group at $\mathrm{C}_{3}$. Compound $\mathrm{IVb}$ shows quartet and triplet in the region $\delta 3.35 \mathrm{ppm}$ and $\delta 1.64 \mathrm{ppm}$ due to $>\mathrm{CH}_{2}$ and $-\mathrm{CH}_{3}$ protons of $-\mathrm{OC}_{2} \mathrm{H}_{5}$ group at $\mathrm{C}_{2}$.

\section{Mass spectra}

The molecular ion peaks of reported compound were in accordance with their molecular weights.

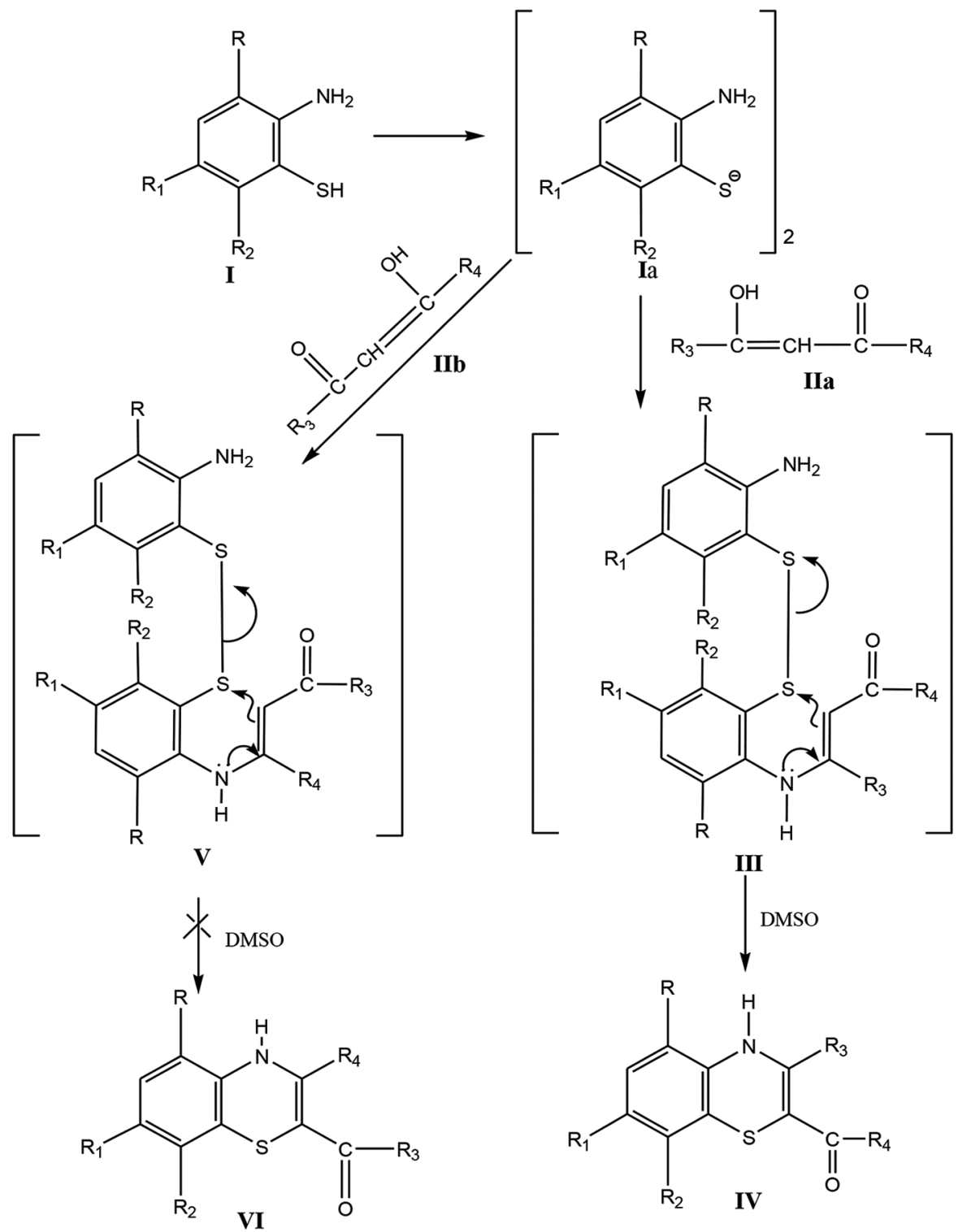

Where

$\mathrm{R}=\mathrm{Cl} ; \mathrm{R}_{1}=\mathrm{Cl} ; \mathrm{R}_{2}=\mathrm{Cl} ; \mathrm{R}_{3}=\mathrm{CH}_{3}, \mathrm{C}_{3} \mathrm{H}_{7} ; \mathrm{R}_{4}=\mathrm{C}_{2} \mathrm{H}_{5}, \mathrm{CH}\left(\mathrm{CH}_{3}\right)_{2}$ 
Table 1: Antimicrobial activity of synthesized compounds

\begin{tabular}{|c|c|c|c|c|c|c|}
\hline \multirow[t]{2}{*}{ Compound No. } & \multicolumn{3}{|c|}{$\begin{array}{l}\text { Minimum inhibitory concentrations of bacterial strains } \\
\text { in } \mu \mathrm{g} / \mathrm{ml}\end{array}$} & \multicolumn{3}{|c|}{$\begin{array}{l}\text { Minimum inhibitory concentrations (MICs) of fungal strains } \\
\text { in } \mu \mathrm{g} / \mathrm{ml}\end{array}$} \\
\hline & $\begin{array}{l}\text { Escherichia coli } \\
\text { MTCC } 2939\end{array}$ & $\begin{array}{l}\text { Bacillus subtilis } \\
\text { MTCC } 441\end{array}$ & $\begin{array}{l}\text { Streptomyces } \\
\text { griseus MTCC } 1998\end{array}$ & $\begin{array}{l}\text { Fusarium oxysporum } \\
\text { MTCC } 1755\end{array}$ & $\begin{array}{l}\text { Aspergillus } \\
\text { niger MTCC } 281\end{array}$ & $\begin{array}{l}\text { Rhizopus stolonifer } \\
\text { MTCC } 2591\end{array}$ \\
\hline IV a & 158 & 41 & 85 & 151 & 78 & 85 \\
\hline IV b & 58 & 124 & 128 & 142 & 59 & 118 \\
\hline Strepto & 68 & 46 & 62 & - & - & - \\
\hline Ketoconazole & - & - & - & 74 & 38 & 46 \\
\hline
\end{tabular}

\section{Antimicrobial assessment}

All synthesized compounds were screened for their antimicrobial activity (antibacterial and antifungal) using agar well diffusion method. Streptomycin and ketoconazole were used as standard antibacterial and antifungal drugs, respectively. Escherichia coli (Gram negative) MTCC 2939, Bacillus subtilis (Gram positive) MTCC 441, and Streptomyces griseus (Gram negative) MTCC 1998 were used for determining antibacterial activity and Fusarium oxysporum MTCC 1755, Aspergillus niger MTCC 281, and Rhizopus stolonifer MTCC 2591 were used for determining antifungal activity of synthesized heterocyclic compounds. The MIC values of synthesized compounds in $\mu \mathrm{g} / \mathrm{mL}$ against certain bacterial and fungal strains are shown in Table 1.

Compound IVa gave excellent results against bacterial strains. Compounds IVb gave excellent results against fungal strains.

\section{Experimental}

The purity of the synthesized compounds was checked by thin layer chromatography using silica gel " $G$ " adsorbent in various non-aqueous solvent systems. Melting points of synthesized compounds are uncorrected and determined in open capillary tubes. IR spectra were recorded in $\mathrm{KBr}$ on SHIMADZU $8400 \mathrm{~S}$ FT IR spectrophotometer. ${ }^{1} \mathrm{H}-\mathrm{NMR}$ spectra have been recorded at $300 \mathrm{MHz}$ on JEOL AL-300 FT NMR using tetramethylsilane as an internal standard in DMSO- $\mathrm{d}_{6}$ (in d ppm).

General procedure for the synthesis of substituted 4H-1,4benzothiazines (IVa-b)

2-Amino-3,5,6-trichlorobenzenethiol (I; 0.01 mole) was refluxed with a stirred suspension of $\beta$-diketones/ $\beta$-ketoesters (IIa; 0.01 mole) in DMSO ( $5 \mathrm{ml}$ ) for 50-60 min. The resulting solution was cooled down to room temperature. The solid separated out was filtered, washed with petroleum ether, and crystallized from methanol.

Isopropyl-5, 7,8-trichloro-3-methyl-4H-1,4-benzothiazine-2-carboxylate (IVa)

Yield $42 \%$, m.p. $172^{\circ} \mathrm{C}$, color: Brown-red; IR (KBr, v): 3465, 1720, 12701080, 2960-2830, 1460-1340, $800 \mathrm{~cm}^{-1}$. ${ }^{1} \mathrm{H}-\mathrm{NMR}(300.40 \mathrm{MHz}$, DMSO-d $)$ : d $9.47(\mathrm{~s}, 1 \mathrm{H}, \mathrm{N}-\mathrm{H}), 8.10(\mathrm{~s}, 1 \mathrm{H}, \mathrm{Ar}-\mathrm{H}), 1.85$ (singlet, $3 \mathrm{H},-\mathrm{CH}_{3}$ protons at $\mathrm{C}_{3}$ ), 4.82 (septet, $1 \mathrm{H},-\mathrm{CH}$ protons of $\mathrm{OCH}\left(\mathrm{CH}_{3}\right)_{2}$ at $\mathrm{C}_{2}$ ), 1.90 (doublet, $6 \mathrm{H},-\mathrm{CH}_{3}$ protons of $\mathrm{OCH}\left(\mathrm{CH}_{3}\right)_{2}$ at $\mathrm{C}_{2}$ ). Anal. calcd. for $\mathrm{C}_{13} \mathrm{H}_{12} \mathrm{NO}_{2} \mathrm{SCl}_{3}: \mathrm{C}, 44.25 ; \mathrm{H}$, 3.40; N, 3.97. Found: C, 44.01; H, 3.51; N, $3.86 \%$.

Ethyl-5,7,8-trichloro-3-propyl-4H-1,4-benzothiazine-2-carboxylate (IVb) Yield $37 \%$, m.p. $112^{\circ} \mathrm{C}$, color: Wine red; IR (KBr, v): 3450, 1710, 1265-1060, 2955-2825, 1455-1335, $810 \mathrm{~cm}^{-1}$. ${ }^{1} \mathrm{H}-\mathrm{NMR}(300.40 \mathrm{MHz}$, DMSO-d ${ }_{6}$ ): d 9.28 (s, 1H, N-H), $8.12(\mathrm{~s}, 1 \mathrm{H}, \mathrm{Ar}-\mathrm{H}), 2.10$ (triplet, $2 \mathrm{H}, \mathrm{H}$ of $\mathrm{CH}_{2}$ (terminal) protons of $\mathrm{C}_{3} \mathrm{H}_{7}$ at $\mathrm{C}_{3}$ ), 1.42 (sextet, $2 \mathrm{H}, \mathrm{H}$ of $-\mathrm{CH}_{2} \mathrm{tC}_{3} \mathrm{H}_{7}$ at $\mathrm{C}_{3}$ ), 3.35 (quartet, $2 \mathrm{H},-\mathrm{CH}_{2}$ protons of $\mathrm{OC}_{2} \mathrm{H}_{5}$ at $\mathrm{C}_{2}$ ), 1.64 (triplet, $3 \mathrm{H},-\mathrm{CH}_{3}$ protons of $\mathrm{OC}_{2} \mathrm{H}_{5}$ at $\mathrm{C}_{2}$ ). Anal. calcd. for $\mathrm{C}_{14} \mathrm{H}_{14} \mathrm{NO}_{2} \mathrm{SCl}_{3}: \mathrm{C}, 45.84 ; \mathrm{H}, 3.82$; N, 3.82. Found: C, 45.62; H, 3.71; N, $3.98 \%$.

\section{Antimicrobial assessment}

Broth microdilution method was used for the evaluation of minimum inhibitory concentrations (MICs, $\mu \mathrm{g} \mathrm{ml}^{-1}$ ) of the synthesized compounds as per NCCLS-1992 manual. Stock solution of $1000 \mu \mathrm{g} / \mathrm{ml}$ concentration for each synthesized compound and standard drugs was prepared in
DMSO. In primary screening, 500, 250, and $125 \mu \mathrm{g} / \mathrm{ml}$ concentrations of the synthesized drugs were taken. The synthesized drugs those found active in primary screening were further tested in a second set of dilution against all microorganisms. These drugs were also diluted to obtain 100, $50,25,20$, and $15 \mu \mathrm{g} / \mathrm{ml}$ concentrations. The highest dilution showing at least $99 \%$ inhibition was taken as MIC which meant that the lowest concentration of each chemical compound in the tube with no growth (i.e. no turbidity) of inoculated bacteria/fungi was recorded as minimum inhibitory concentration of that compound. Antibacterial activities of the bacterial strains were carried out in Luria broth (HiMedia) medium and all fungi were cultivated in Sabouraud dextrose agar (HiMedia) at $\mathrm{pH}$ 6.9 with an inoculum of $10^{8} \mathrm{cfu} / \mathrm{ml}$ by the spectrophotometric method and an aliquot of $10 \mathrm{ml}$ was added to each tube of the serial dilution and incubated on a rotary shaker at $37^{\circ} \mathrm{C}$ for $24 \mathrm{~h}$ at $150 \mathrm{rpm}$. At the end of incubation period, MIC values were recorded.

The MIC values of synthesized compounds in $\mu \mathrm{g} / \mathrm{ml}$ against certain bacterial strain and fungal strain are shown in Table 1.

\section{CONCLUSION}

Novel prospective bioactive substituted $4 H$-1,4-benzothiazines were synthesized using available starting materials and investigated by spectral and elemental analysis. Significant antibacterial and antifungal activities (MIC values) were exhibited by synthesized compounds against selected strains of bacteria and fungi due to strong electronwithdrawing groups. A slight change in substitution pattern affects the biological activity tremendously. Benzothiazines templates have potential to be used as a new class of antibacterial and antifungal drugs. Further biomedical research is required to make $4 H$-1,4-benzothiazines related compounds as potential antibacterial and antifungal drugs.

\section{ACKNOWLEDGMENTS}

The author is grateful to the Department of Chemistry, University of Rajasthan, Jaipur, and Govt. P.G. College, Rajgarh (Alwar), for providing necessary facilities. Authors are also thankful to Institute of Seminal Applied Sciences, Jaipur, for carrying out antimicrobial activity of synthesized compounds.

\section{AUTHOR'S CONTRIBUTIONS}

Author has synthesized all the compounds, data collection and analysis, results, and methods discussion to complete the final manuscript. Prof. D.C. Gautam supervised the entire synthesized work.

\section{CONFLICTS OF INTEREST}

The author declares that he has no conflicts of interest.

\section{AUTHOR'S FUNDING}

The author is also grateful to the UGC and CSIR, New Delhi, for providing financial support.

\section{REFERENCES}

1. Kajino M, Mizuno K, Tawada H, Shibouta Y, Nishikawa K, Meguro K. Synthesis and biological activities of new 1, 4-benzothiazine derivatives. Chem Pharm Bull 1991;39:2888-95. 
2. Grandolini G, Luana P, Ambrogi V. Synthesis of some new 1, 4-benzothiazine and 1, 5-benzothiazepine tricyclic derivatives with structural analogy with TIBO and their screening for anti-HIV activity. Eur J Med Chem 1999;34:701-9.

3. Munde SB, Bondge SP, Bhingolikar VE, Mane RA. A facile synthesis of 1, 4-benzothiazines under solvent free conditions. Green Chem 2003;5:278-9.

4. Eicher T, Hauptmann S, Speicher A. The Chemistry of Heterocycles: Structure, Reactions, Syntheses and Application. Weinheim: WileyVCH; 2003.

5. Deshmukh MB, Mulik AR, Desai SD. Sysnthesis of some new 2-methyl-1, 4-benzothiazin-3-(1H)-one derivatives as potential vasodilator. Eur J Chem 2004;1:206-10.

6. Dabholkar VV, Gavande RP. Synthesis of pyrazolyl 1, 4-benzothiazine derivatives. Heteroletters 2011;3:255-61.

7. Gupta K. Microwave assisted facile synthesis of some substituted $4 \mathrm{H} 1$, 4-benzothiazine. Indian J Chem 2011;9:1625-8.

8. Gautam N, Ajmera N, Gupta S Gautam DC. Synthesis, spectral characterization and biological evaluation of $4 \mathrm{H}-1$, 4-benzothiazines, their sulfones and ribofuranosides. Eur J Chem 2012;3:106-11.

9. Saari WS, Cochran DW, Lee YC, Cresson EL, Springer JP, Williams M. Preparation of some 10-[3-(dimethylamino)-1-propyl]-10H-pyrazino[2, 3-b] [1, 4] benzothiazines as potential neuroleptics. J Med Chem 1983;26:564-9.

10. Chikuma T, Ishii Y, Kato T, Kurihara N, Hakeda Y, Kumegawa M. Effect of chlorpromazine on PZ-peptidase and several other peptidase activities in cloned osteoblastic cells (MC3T3-E1). Biochem Pharmacol 1987;36:4319-24.

11. Gupta RR, Ojha KG. In: Gupta RR, editor. Phenothiazines and 1, 4-benzothiazines: chemical and biomedical aspects. Amsterdam:
Elsevier; 1988. p. 163-269.

12. Gupta RR. Phenothiazines and 1, 4-Benzothiazines-Chemical and Biomedical Aspects. Amsterdam: Elsevier; 1988

13. Teodori E, Dei S, Scapecchi S, Gualtieri F. The medicinal chemistry of multidrug resistance (MDR) reversing drugs. Farmaco 2002;57:385-415.

14. Khandelwal N, Abhilasha, Gautam N, Gautam DC. An efficient synthesis and biological study of substituted 8-chloro-5-methoxy/8chloro-4H-1, 4-benzothiazines, their sulphones and ribofuranosides. J Chem Sci 2013;125:85-93.

15. Dogan HN, Duran A, Rollas S, Sener G, Uysal MK, Gulen D. Synthesis of new 2, 5-disubstituted-1, 3, 4-thiadiazoles and preliminary evaluation of anti-convulsant and antimicrobial activities. Bioorg Med Chem 2002;10:2893-8.

16. Zamani K, Faghihi K, Tofighi T, Shariatzadeh MR. Synthesis and antimicrobial activity of some pyridyl and naphthyl substituted 1, 2, 4-triazole and 1, 3, 4-thiadiazole derivatives. Turk J Chem 2004:28:95-100.

17. Dabholkar VV, Gavande RP. Synthesis and antimicrobial activities of novel 1, 4-benzothiazine derivatives. Arab J Chem 2011;9:S225-9.

18. RathodAK. A microwave-assisted synthesis of some new benzothiazines derivatives and their antimicrobial activity. Int J Pharm Sci Rev Res 2013; $18: 47-9$

19. Kaneko T, Clark RS, Ohi N, Kawahara T, Akamatsu H, Ozaki F. Inhibitors of adhesion molecules expression; the synthesis and pharmacological properties of 10H-pyrazino [2, 3-b] [1, 4] benzothiazine derivatives. Chem Pharm Bull 2002;50:922-9.

20. Gautam N, Ajmera N, Gupta S, Gautam DC. Synthesis, spectral characterization and biological evaluation of $4 \mathrm{H}-1$, 4-benzothiazines, their sulfones and ribofuranosides. Eur J Chem 2012;3:106-11. 